\title{
Clusters in the Renewable Energy Sector in Poland
}

\author{
Michał Staszków \\ Poznan University of Economics and Business, Poland \\ michal.staszkow@ue.poznan.pl \\ Michał Borychowski \\ Poznan University of Economics and Business, Poland \\ michal.borychowski@ue.poznan.pl \\ Filip Nowacki \\ Poznan University of Economics and Business, Poland \\ filip.nowacki@ue.poznan.pl
}

The paper is a review work, which presents the problem of a renewable energy in Poland supplemented with a case study. To reduce gas emission and to improve energy efficiency the European Union's Member States are obliged to obtain more energy from renewable sources. Our goal is to test how cluster may help in achieving the provisions of $3 \times 20 \%$ package. The case study of Baltic Eco-Energy Cluster is presented as a successful example of the biggest energy cluster in the country, which can be treated as a benchmark for other sector clusters that are willing to contribute positively to changes in Polish energy sector.

Key Words: clusters, renewable energy, $3 \times 20 \%$ package

JEL Classification: E00, O13, P28, Q20, Q4

https://doi.org/10.26493/1854-6935.15.275-29o

\section{Introduction}

The very concept of a cluster is not new, but there is a lack of scientific studies that explore clusters in the renewable energy sector. Polish law does not specify clearly the concept of the cluster, and the law on renewable energy sources came into force in February 2015. In the presented paper, the authors conduct a critical literature review on the topic of clusters and renewable energy industry. Analysis of the literature concerns scientific papers, regulations and law provided by the European Union, as well as the websites of the Polish Agency for Enterprise Development and the various clusters in Poland and the European Union. The adopted time range of analysis is 2004-2014, mainly due to the date of Poland's accession to the European Union. The authors prepared a case study of 
the Baltic Eco-Energy Cluster (B E EC) based on the website of the Polish Agency for Enterprise Development. Despite the fact that in each region of Poland there are different clusters focused on the topic of renewable energy, it seems that only this one presented cluster has a great potential for success.

Baltic Eco-Energy Cluster located in the north of Poland (which contributes mostly to the production of a renewable energy in the country) is the biggest energy cluster and the most active one. Therefore, this cluster is a subject of prepared case study, which aims to present a tips and solutions for other clusters that may benchmark against B EEC and improve their own organization model. The case study is based on secondary data from websites and branch reports. The data for a whole paper will be supplemented with secondary data, mainly from the Central Statistical Office of Poland and the data available on the website of the European Commission (Eurostat).

The main aim of this paper is to identify and present the concept of clusters in the renewable energy sector in Poland. In 2007, the European Commission presented the climate and energy package briefly named $3 \times$ $20 \%$ package. It imposes a reduction in greenhouse gas emissions by at least $20 \%$, compared to year 1990 . The other objective of the package is to increase the share of renewable energy in final energy consumption by $20 \%$ (for Poland it is reduced to $15 \%$ ) and increase in energy efficiency by $20 \%$. All of these goals are to be met by 2020 . In the paper, the authors would like to examine whether the clusters in the renewable energy sector in Poland have a chance to support fulfilling the goals of the $3 \times 20 \%$ package.

Preliminary literature review allows creating some hypothesis on the subject addressed. The location of cluster will not be probably determined by natural factors (existence of water bodies or favourable wind conditions), but economic and political factors, associated with the $\mathrm{E} U$ funds. Thanks to those funds, clusters in the renewable energy sector have the opportunity for further development, and thus can become an effective tool for the implementation of the $3 \times 20 \%$ package. Another problem are the global benefits of artificially imposed European Union's climate and energy package. It can occur that the energy-intensive production will be transferred to countries, which are not restricted with climate package. Such situation surprisingly could cause more problems (mainly economic) for Eu Member States than not fulfilling the goals of climate and energy package. 


\section{Clusters: Literature Review}

In Poland, there are many ongoing initiatives and projects referring to the concept of cluster. Objectives and structure of these projects, however, have a large variation. The most common definition of a cluster was developed by Porter (1998), according to whom a cluster is a group of companies existing in a geographical neighbourhood along with the institutions, which are related to them and deal with a particular activity, connected by similarities and competing with one another. The most important in this definition are relationships, cooperation and territorial bonds, which in consequence should generate added value and lead to a competitive advantage on the market (Ratajczak-Mrozek and Herbeć 2013).

Following papers of Jankowska and Pietrzykowski (2013), Ketels (2004) defined main attributes of clusters:

- Proximity: the entities need to be sufficiently and spatially close to permit positive spill-over and enable the sharing of common resources to occur;

- Linkages: their activities need to share a common goal for them to be able to profit from proximity and interactions;

- Interactions: being close and working on related issues does not seem to be enough - some level of interaction is essential;

- Critical mass: a sufficient number of participants being present is required for the interactions to have a meaningful impact on companies.

Similar definition was provided by European Commission (2003): Clusters are groups of independent companies and associated institutions that are:

- Collaborating and competing;

- Geographically concentrated in one or several regions, even though the cluster may have global extensions;

- Specialized in a particular field, linked by common technologies and skills;

- Either science-based or traditional;

- Clusters can be either institutionalized (they have a proper cluster manager) or non institutionalized.

According to above-mentioned definitions, there are usually several parties in cluster initiatives. Those are first of all entrepreneurs, but also 


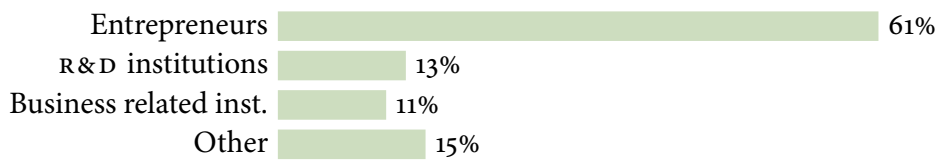

FIGURE 1 Entities Identified as Participants in Clusters and Cluster Initiatives Related to Energy in Poland (adapted from Feltynowski and Rzeńca 2012)

financial institutions, public entities - such as local authorities, universities, media and organizations stimulating cooperation (Jankowska 2011). The situation in which the initiative to establish the cluster goes out of firms and is managed by them is so-called bottom-up approach, in contrary to top-down approach, where activities are undertaken by public authorities. Bottom-up model seems to be more effective because it arises from the need of the market (as can be seen in case study of Baltic EcoEnergy Cluster, paragraph 3). This does not exclude cooperation with public authorities and public institutions, but allows building trust, which in effect brings specific benefits (Cook and Morgan 2002):

- Improving the economic efficiency by saving time and effort related to specific activities, because they can rely on the word of partner;

- Reduction of the risk associated with the activity;

- The development of the ability to learn by the fact that institutions and companies are parties in the process of information exchange.

The results of research conducted by Feltynowski and Rzeńca (2012) (see figure 1) indicate that the structure of the participants of clusters in Poland favours and confirms bottom-up model.

In addition to mentioned benefits, cluster development can contribute to faster economic growth, increase productivity and profits, attract FDI (foreign direct investment), increase exports and create new jobs thanks to the dynamic growth in the number of enterprises. The resulting competitive advantage given location manifests itself nationally and often internationally. Feltynowski and Rzeńca (2012) determined goals of clusters active in renewable energy sources (RES) sector:

- The use and promotion of the region's potential in the field of RES;

- Maximizing the use of existing local potential energy (wind power development, based on biomass and others);

- Stimulating activities to improve energy efficiency in businesses, households, public buildings; 
- Improving energy efficiency leading to energy savings in three areas: final usage, in industry and in the distribution and finally in manufacture;

- Improving local energy security;

- Promotion of Polish energy and environmental technologies;

- Promoting innovation in environmental protection and energy;

- Minimizing financial, organizational, technical and mental barriers;

- Environmental education in all mentioned areas.

Poland provides favourable conditions for the development of innovations and entrepreneurship. In recent years, mainly thanks to the $\mathrm{EU}$ funds, in Poland were created many business-related institutions aimed at supporting the business and science in the implementation of various types of business ventures and $\mathrm{R} \& \mathrm{D}$ (research and development). These institutions offer, among others, office space, specialized laboratories equipment and specialized business consulting. In 2010, a total of 735 work centres for innovation and entrepreneurship were active, including 24 technology parks, 40 business incubators, 90 technology transfer centres and 317 training, consulting and information services (Polska Agencja Rozwoju 2012). According to Polish Enterprise Development Agency, until end of 2015 there were 130 established clusters in Poland (Buczyńska, Frączek, and Kryjom 2016).

Analysis of the structure of Polish cluster initiatives shows that clusters exist in sectors that are considered innovative, as well as more traditional. The most common sector is ICT (information and communications technology) (19 clusters), eco-energy (16) and construction (12), medicine and biotechnology (11). As can be seen, the eco-energy sector is highly ranked among clusters in Poland, as well as the biotechnological clusters that have been described by Puślecki and Staszków (2015). To understand the reason, it is important to explain the role of so-called climate and energy package.

\section{Renewable Energy Sector in the European Union}

As a result of the adoption in 2007 by the European Union the so-called climate and energy package $(3 \times 20 \%)$ the $\mathrm{EU}$ is required to achieve until year 2020 three following key objectives (European Parliament and the Council 2009): (1) to reduce greenhouse gas emissions by at least $20 \%$ compared to $1990 ;$ (2) to improve energy efficiency by $20 \%$; (3) to increase 
the share of renewable energy in total energy consumption to $20 \%$, including $10 \%$ of biofuels in overall fuel consumption in transport. Renewable energy sources include wind, solar, hydro, geothermal, biomass. In fact, $20 \%$ for three objectives is valid in the European Union as a whole, and in the member states, the objectives differ from $20 \%$. This applies to both the size of the planned reduction of carbon dioxide (or even planned increase of emissions) and to improve energy efficiency and the share of energy from renewable sources in gross final energy consumption. Only the target for the share of biofuels in transport fuels of $10 \%$ is applicable in all member states.

In Poland, the share of renewable energy in the total energy consumption by 2020 is expected to reach $15 \%$ due to limited resources and the efficiency of renewable energy sources (RES). At the same time there is a possibility that in Poland by 2020 compared to 2005 greenhouse gas emissions will increase in selected sectors of the economy (up by 14\%) due to lower Gross Domestic Product (GDP) per capita than the average in the EU (Energia i Środowisko n. d.). As a result, the Polish economy is to remain more competitive (using smaller environmental constraints). This is to allow catching up with more developed Eu countries. There are some reasons for development of the renewable energy sector, among others (European Parliament and the Council 2009; Rifkin 2012):

- The ability to reduce its dependence on energy imports (mainly crude oil, natural gas) and strengthening energy security;

- Significant economic benefits and positive stimulus for the economy - progress and technological development, creation of new jobs in the internal market (in the $\mathrm{EU}$ ), including rural areas;

- Environmental protection and indirect responsibility for the environment in the countries exporting energy resources to the $\mathrm{EU}$;

- Renewable nature and natural origin.

According to the directive, these objectives are appropriate and achievable. They offer companies also stability of their potential investments. Those goals must be achieved cost-effectively (European Parliament and the Council 2009), suggesting that economic factors should be more important than imposed from administrative regulations. Meanwhile the cost-effectiveness (economical and environmental) of certain investments in renewable energy sources is questionable and sometimes undermined. Other issues and concerns referring to the package $3 \times 20 \%$, and regarding Poland are as follows (PA P 2015): 
- Lack of diversification of energy supply sources and the dominance of coal as an energy source (in Poland - more than 90\% of electricity is produced from coal and lignite);

- Economic development is associated with an increase in demand for energy, thus increasing environmental requirements may even inhibit economic development;

- The risk of non-competitive renewable energy sector in comparison to the traditional energy sector, which could lead to the transfer of energy-intensive production outside the $\mathrm{EU}$;

- Consequences of political instability and unpredictability - in Poland the law on renewable energy sources came into force only in February 2015 thus this industry was not properly regulated for a long time.

Except of a number of ongoing discussions on the above package, set were further targets for climate and energy in the range of competitive, secure and low-carbon EU economy for the year 2030. They plan to cut greenhouse gas emissions by $40 \%$ below 1990 levels and to increase the share of energy from renewable sources to $27 \%$ (this target is not a binding target for each Member State, but for the whole EU) (European Commission 2014). In August 2014, the Committee of the Regions ${ }^{1}$ stated that it should adopted more ambitious targets for the new climate and energy package. It is about reducing greenhouse gas emissions by $50 \%$ compared to 1990 , achieving the share of energy from renewable sources at $40 \%$ and the reduction of primary energy consumption by $40 \%$ compared to 2005 (Opinion 2014). These objectives are aimed to avoid warming exceeding 2 degrees Celsius and achieve long-term EU target for reducing greenhouse gas emissions by $80-95 \%$. It seems that these demands are not available in some Member States, because there are problems now - with implementation of the package $3 \times 20 \%$. Finally, during the negotiations at the European Council in October 2014 from the Polish point of view they managed to achieve relatively favourable results, i.e. reducing emissions by $40 \%$ compared to 1990 and the share of RES of $27 \%$ by 2030 . In terms of energy efficiency improvements at the level of the $\mathrm{EU}$ was established indicative target of at least 27\% (European Council 2014).

Table 1 presents some data on the implementation of one of the basic objective of the package $3 \times 20 \%$ - the share of energy from renewable sources in all Members States of the European Union in 2013 and targets for 2020. By calculating these indicators the energy consumption in ev- 
ery country was taken into account, and as mentioned, the value of this indicator in different countries differ from each other, as they depend on the state of economic development and the potential for growth in the production of energy from renewable sources (resource capabilities).

It is worth noting that the objective of the share of renewable energy in 2020 at the level of more than $20 \%$ (the average share of the $\mathrm{EU}$ ) have both some developed countries and less developed countries. On the other hand, the level of $20 \%$ or the lower level was planned in some rich and poor countries when the level of GDP per capita is taken into account. The share of energy from renewable sources in excess of $20 \%$ is realized, inter alia, in the Scandinavian countries (Sweden $49 \%$, Finland 38\%, Denmark $30 \%$ ), in Austria (34\%) and France (23\%), but also in the Baltic States (Estonia 25\%, Lithuania 23\%, Latvia 40\%), in Portugal (31\%), Romania (24\%) and Slovenia (25\%). The share of less than $20 \%$ is in some old Member States, among others: Belgium, Germany, Great Britain, Greece, Ireland, Italy, the Netherlands, as well as in the new Member States (which joined the EU in 2004 and later) - Bulgaria, Czech Republic, Hungary, Poland, Slovakia.

It is worth to look also at the degree of achievement of expected demands. Some of the countries already in 2013 reached 2020 plan including Sweden, Austria, Bulgaria and Estonia. Especially the first two countries are leaders in the development of the renewable energy sector. However in other situations (very low level of implementation of the targeted share of renewable energy) are inter alia the Netherlands (4.8\% compared with $14 \%$ of the plan, resulting in the degree of implementation at the level of $34 \%$ ) and the UK (the share of $4.9 \%$ to $15 \%$ of the plan, which gives the degree of implementation of less than $33 \%$ ). In Poland, currently close to $11.5 \%$ of the energy is produced from renewable sources. This means that the plan for 2020 is implemented in around $76 \%$, which poses a real chance that Poland will achieve its goal in a few years. In similar situations are Germany, Hungary, Slovakia and Spain. The higher degree of implementation (over 90\%) have two Scandinavian countries - Denmark and Finland and three new Member States - Latvia, Lithuania and Romania. It can be assumed that the continuation of the development of renewable energy sector in these countries will let to fulfil and maintain their own objectives to 2020.

According to data from the Central Statistical Office, the share of renewable energy in total energy consumption is growing. It can be seen mainly in northern Poland (see figure 2), which is associated on the one 
TA B LE 1 Renewable Energy Sources Share in European Union in 2013 and Target for $2020(\%)$

\begin{tabular}{|c|c|c|c|}
\hline Specification & $\begin{array}{r}\text { The share of } \\
\text { renewable energy } \\
\text { sources in } 2013\end{array}$ & $\begin{array}{r}\text { The targeted share } \\
\text { of renewable energy } \\
\text { sources in } 2020\end{array}$ & $\begin{array}{l}\text { The current level of } \\
\text { implementation }\end{array}$ \\
\hline Austria & 34.5 & 34 & 101.5 \\
\hline Belgium & 7.4 & 13 & 56.9 \\
\hline Bulgaria & 17.2 & 16 & 107.5 \\
\hline Croatia & 17.9 & 20 & 89.5 \\
\hline Cyprus & 6.8 & 13 & 52.3 \\
\hline Czech Republic & 11.4 & 13 & 87.7 \\
\hline Denmark & 27.6 & 30 & 92.0 \\
\hline Estonia & 26.1 & 25 & 104.4 \\
\hline Finland & $34 \cdot 9$ & 38 & 91.8 \\
\hline France & 13.7 & 23 & 59.6 \\
\hline Germany & 12.9 & 18 & 71.7 \\
\hline Greece & 15.8 & 18 & 87.8 \\
\hline Hungary & 9.8 & 13 & 75.4 \\
\hline Ireland & 8.2 & 16 & 51.3 \\
\hline Italy & 14.6 & 17 & 85.9 \\
\hline Latvia & 36.0 & 40 & 90.0 \\
\hline Lithuania & 22.0 & 23 & 95.7 \\
\hline Luxembourg & $3 \cdot 3$ & 11 & 30.0 \\
\hline Malta & 1.8 & 10 & 18.0 \\
\hline Netherlands & 4.8 & 14 & $34 \cdot 3$ \\
\hline Poland & 11.4 & 15 & 76.0 \\
\hline Portugal & 25.8 & 31 & 83.2 \\
\hline Romania & 23.8 & 24 & 99.2 \\
\hline Slovakia & 10.7 & 14 & 76.4 \\
\hline Slovenia & 20.7 & 25 & 82.8 \\
\hline Spain & 14.9 & 20 & 74.5 \\
\hline Sweden & 56.0 & 49 & $114 \cdot 3$ \\
\hline United Kingdom & $4 \cdot 9$ & 15 & 32.7 \\
\hline EU 28 & 14.9 & 20 & 74.5 \\
\hline
\end{tabular}




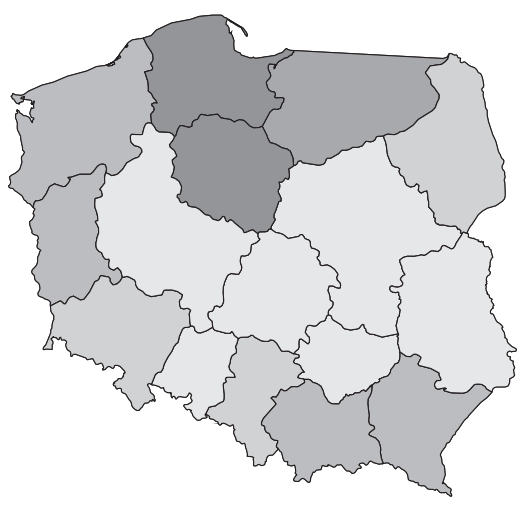

Less than $1 \%$ $1.00-3.00 \%$ $3.01-7.50 \%$

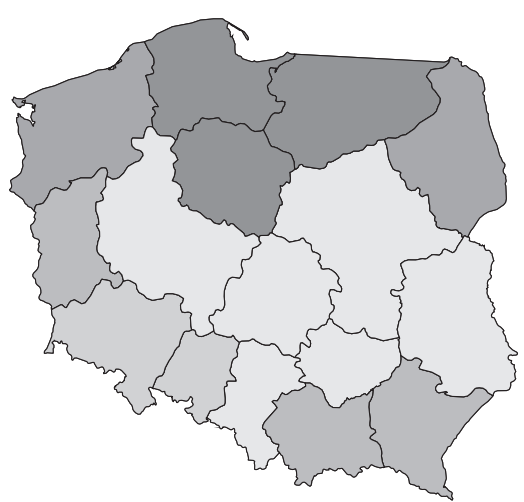

$7.51-16.00 \%$
More than $16 \%$

FIgURE 2 The Share of Renewable Energy in Total Energy Production in Regions in 2005 and 2009 (adapted from Feltynowski and Rzeńca 2012)

TABLE 2 Structure of Use of Renewable Energy Sources in Poland in 2004-2015 (\%)

\begin{tabular}{lrrrr}
\hline Year & $\begin{array}{r}\text { Renewable energy } \\
\text { sources }- \\
\text { Electricity }\end{array}$ & $\begin{array}{r}\text { Renewable energy } \\
\text { sources - } \\
\text { Transport }\end{array}$ & $\begin{array}{r}\text { Renewable energy } \\
\text { sources } \\
\text { and Cooling }\end{array}$ & $\begin{array}{r}\text { Renewable energy } \\
\text { sources }\end{array}$ \\
\hline 2004 & 2.1 & 0.9 & 10.2 & 6.9 \\
2005 & 2.7 & 0.8 & 10.1 & 6.9 \\
2006 & 3.0 & 1.1 & 10.2 & 6.9 \\
2007 & 3.5 & 1.5 & 10.4 & 6.9 \\
2008 & 4.4 & 4.0 & 10.9 & 7.7 \\
2009 & 5.8 & 5.3 & 11.6 & 8.7 \\
2010 & 6.6 & 6.6 & 11.7 & 9.2 \\
2011 & 8.2 & 6.8 & 13.1 & 10.3 \\
2012 & 10.7 & 6.5 & 13.4 & 10.9 \\
2013 & 10.7 & 6.6 & 14.1 & 11.4 \\
2014 & 12.4 & 6.2 & 14.0 & 11.5 \\
2015 & 13.4 & 6.4 & 14.3 & 11.8 \\
\hline
\end{tabular}

NOTES Based on data from Eurostat (http://ec.europa.eu/eurostat).

hand with favourable natural conditions, while on the other with the activity of energy clusters, such as Baltic Eco-Energy Cluster.

Table 2 analyses the structure of energy consumption from renewable sources divided into the consumption of electricity, heating and cooling, and transport, in relation to the total energy consumption in a given area. 
Relatively minor importance in the early years were RES for electricity and transport. With time, however, it was changed. In 2004, electricity was obtained primarily from the water, followed by solid biofuels, but over time, this trend was reversed. Currently, the most important renewable source of electricity are just solid biofuels, then wind and hydro. The share of renewable energy sources in gross final consumption in Poland is currently (in 2013) of $11.3 \%$. According to the strategy of indirect objectives (indicative trajectory) designated by the EU, Poland should achieve in 2013-2014 the share of 9.5\%. This means that Poland is well on the way to 2020 to achieve its target for renewable energy.

\section{Baltic Eco-Energy Cluster Case Study}

Even despite the fact that in Poland are located more than 20 clusters focused on a renewable energy sector (Feltynowski and Rzeńca 2012), only a few of them are active entities. Some of the existing clusters are not conducting any activities, while some others are active to a very limited extent. The cluster, which is a distinguishing one, which other clusters may even benchmark against, is the Baltic Eco-Energy Cluster.

The Baltic Eco-Energy Cluster was established in 2007, so it is not the oldest one. Therefore, it may be presumed that the factor of the length of the existence on the market is not the dominating element of a success. However, most of the clusters in renewable energy were established in years 2006-2009, when Polish Agency for Enterprise Development was financially supporting a positive attitude against such cluster initiatives. It may be the reason of the existence of a number of inactive clusters that were established on the wave of their boom and positive prosperity. Even though the Baltic Cluster is located in Gdańsk, like it was stated earlier, the city of location is not a very strict factor. It is only the main head office of cluster's coordinator. In the cluster included are entities from three regions, namely Kujawsko-Pomorskie, Pomorskie and WarmińskoMazurskie, so Gdańsk is important city but does not play a dominant role within the cluster.

In each of mentioned regions, energy production from renewable resources was very important. In 2009 in Warmińsko-Mazurskie 42\% of produced energy came from renewable resources, while in KujawskoPomorskie over one-third and Pomorskie almost one-third (Feltynowski and Rzeńca 2012). It confirms the great importance of renewable energy in this region of Poland and a positive attitude against new technologies. Therefore, it is not surprising that within two years of a time of creation, 
Baltic Eco-Energy Cluster was the most important cluster in the region.

According to the most relevant data (http://www.imp.gda.pl/projekty/ bkee/uczestnicy), the BEEC consists of 174 entities, including:

- 133 enterprises;

- 14 government entities (small communities, towns and municipal offices);

- 14 science entities (high schools and universities);

- 13 other institutions (foundations, etc.).

While it is believed that due to a maintenance and management issues a number of participants of energy cluster should not exceed 40 entities (Mazowiecka Agencja Energetyczna 2013) this cluster stays in opposition. The reason is that, this cluster is administrated by Gdański Instytut Maszyn Przemysłowych (Gdansk Institute for Industrial Machinery), that coordinates all cluster activities. Therefore the large number of participants instead of being a problem for a cluster determines its strength. The coordinator cannot dominate over other entities and be a competitive unit. In case of B EE C, Gdansk Institute for Industrial Machinery helps in raising external financial funds and establishing collaboration between science and business. Also small clusters may achieve a competitive advantage from specialization. They should focus on some niche as Ekologiczny Dom Energooszczędny (Ecological Energy Efficient Home), where market is not so strongly saturated and then strive for perfection in this specific area.

One of the main companies involved in BEEC is Energa, one of the biggest energy companies in the country. In most of the cases such, a big partner could act as a threat for other smaller companies. In Baltic Cluster, the relations between engaged companies and institutions were solved to satisfy all participants. Energa is included only in the biggest research projects, so smaller companies can gain experience through cooperation and play the main role in smaller projects. Thanks to that, all companies are satisfied and potential of each of them is fully exploited.

In some cases participants of a cluster (mostly in its initial stage), may suffer from not possessing a legal personality. It may be solved by the usage of a legal personality of a coordinator of a cluster or one of its participants (what happened at the beginning also in BEEC). It is even easier when a cluster consists of a large number of participants.

The main aim of Baltic Cluster is to introduce and promote a widely understood idea of distributed co-generation, understood as simultane- 
ous small and medium scale production of thermal energy and electricity from renewable energy sources, mainly biomass, but also by converting water, solar and wind energy. The advantage of big clusters like BEEC is a possibility of being active in many areas. $\mathrm{BEEC}$, due to a large number of involved entities is active in four main spheres of activities:

- Raw materials based mostly on using biomass;

- Research and Development focused on development of new technologies and competitiveness of involved companies in terms of machinery;

- Creating energy from renewable resources and development of small biomass producers;

- Production of machinery for a purpose of bio energy.

The Baltic Cluster is active through all stages of work - in - projects as it is involved both, in development of new research projects and their implementation. It is also active in international environment, taking active part in meetings of European Commission advisory groups, international projects, conferences or workshops. The cluster is also aware of the importance of good Public Relations. Therefore, it cares about a promotion and organizes conferences, seminars and competitions for junior schools.

For the success of BEEC, very important role-plays a support from involved governmental entities. In case when a cluster does not consist of such entities, it is necessary to ensure a formal cooperation with cities and institutions. Another important factor is a strong support from science to BEEC. Because this cluster works together with the best local technology universities, high schools of economy and management and machinery institutes, it has a direct access to knowledge resources. It may not suffer from a scarcity of well-educated people, who strongly contributes to the newest technologies used in renewable energy sector. Clusters based on an expertise that comes from Research and Development work has a great possibility of receiving attractive funds from grants. More applications for grants does cluster send, increased is its experience. BEEC is also an example of open cluster, which co-operates also with other clusters (from their proximity). Because to some extent all energy clusters are working on similar tasks, it is much easier for them to co-operate and even together apply for some external financial resource. The successful collaboration between BEEC and relatively very small (with 16 entities) Nadwiślański Klaster Energii Odnawialnej (Vistula River Valley Energy Cluster) may encourage other clusters to consider working together. Big 
clusters gain knowledge from niche market, while small entity has access to greater resources. The only important thing is to have a common goal, which both clusters want to achieve.

Based on Baltic Eco-Energy Cluster, clusters focused on renewably energy that are interested in success should follow the following rules:

- Cluster has to be open place, without limit of number of participants and willing to collaborate with other clusters and institutions;

- Applying for external funds is very important for the functioning of the cluster;

- The role of coordinator needs to be made carefully to choose entity, which will not dominate other participants.

\section{Conclusions}

The idea of clusters was known many years, but in Poland, it was developed mainly in the last decade thanks to the $\mathrm{EU}$ funds. Clusters are considered to be a tool which helps developing innovativeness and improving the competitiveness of companies, cities or entire regions. Boom on clusters however causes that this term is overused and often used unduly. Some clusters are dead formations, created with funds from the $\mathrm{EU}$, in which innovation and cooperation does not have a chance to be developed. At the end of 2015, there were 130 clusters in Poland, of which 16 supposed to represent eco-energy sector. This is an area where the concept of clustering has greater sense of existence and where well-managed clusters can be a tool for achieving the objectives of the climate package. The case study of Baltic Eco-Energy Cluster is presented as example of successful and the biggest energy cluster in the country, which may act as a benchmark for other sector clusters that are willing to contribute positively to changes in Polish energy sector.

\section{Notes}

1 Committee of the Regions is a consultative body for the institutions of the European Union (European Commission, Council of the European Union, the European Parliament), which represents local and regional authorities in the $\mathrm{EU}$.

\section{References}

Buczyńska, G., D. Frączek, and P. Kryjom. 2016. Raport z inwentaryzacji klastrów w Polsce 2015. Warsaw: Polska Agencja Rozwoju Przedsiębiorczości. 
Cooke, P., and K. Morgan. 2002. The Associational Economy: Firms, Regions and Innovation. New York: Oxford University Press.

Energia i Środowisko. N. d. 'Pakiet klimatyczno-energetyczny.' http://www .energiaisrodowisko.pl/zarzadzanie-energia-i-srodowiskiem/pakietklimatyczno-energetyczny

European Commission. 2003 'Final Report of the Expert Group on Enterprise Clusters and Networks.' European Commission, Brussels.

- 2014. '2030 Climate and Energy Goals for a Competitive, Secure and Low-Carbon E U Economy' Press release, 22 January. http://europa .eu/rapid/press-release_IP-14-54_en.htm

European Council. 'Conclusions on 2030 Climate and Energy Policy Framework.' EUCO 169/14, European Council, Brussels.

European Environment Agency. 2015. Renewable Energy in Europe: Approximated Recent Growth and Knock-on Effects. Luxembourg: Publications Office of the European Union.

European Parliament and the Council. 2009. 'Directive 2009/28/EC of the European Parliament and of the Council of 23 April 2009 on the Promotion of the Use of Energy from Renewable Sources and Amending and Subsequently Repealing Directives 2001/77/EC and 2003/30/EC.' Official Journal of the European Union, L 140.

European Union. 2014. 'Opinion: A Policy Framework for Climate and Energy in the Period from 2020 to 2030.' ENVE-V-047, Committee of the Regions. https://webapi.cor.europa.eu/documentsanonymous/COR -2014-02691-oo-oo-AC-TRA-EN.doc/content

Feltynowski, M., and A. Rzeńca. 2012. Klastry energetyczne w Polsce. Szczecin: Uniwersytet Szczeciński.

Jankowska, B. 2011. 'Klastry na usługach innowacyjności przedsiębiorstw.' In Przedsiębiorstwo na rynku międzynarodowym, edited by J. Schroeder, 67-77. Poznan: Wydawnictwo Uniwersytetu Ekonomicznego w Poznaniu.

Jankowska, B., and M. Pietrzykowski. 2013. 'Clusters as Absorbers and Diffusers of Knowledge.' Poznań University of Economics Review 13 (1): 6888.

Ketels, C. H. M. 'European Clusters.' In Innovative City and Business Regions, vol. 3, edited by T. Mentzel, 1-5. Bollschweil: Hagbarth.

PA P. 2015. 'Sejm uchwalił ustawę o odnawialnych źródłach energii.' wnp.pl Portal Gospodarczy, 16 January. http://energetyka.wnp.pl/sejm-uchwalil -ustawe-o-odnawialnych-zrodlach-energii,242496_1_o_o.html

Polska Agencja Rozwoju. 2012. Klastry w Polsce: Katalog. 2012. Warsaw: Polska Agencja Rozwoju Przedsiębiorczości.

Mazowiecka Agencja Energetyczna. 2013. 'Analiza rynku klastrów energetycznych i innych w środowisku polskim, niemieckim i francuskim - 
raport z badania Desk Research.' http://www.mae.com.pl/files/analizaklastrow_www-tryb-zgodnosci.pdf

Porter, M. E. 1998. 'Clusters and the New Economics of Competition.' Harvard Business Review 76 (6): 77-90.

Puślecki, Ł., and M. Staszków. 2015. 'New Cooperation Modes: An Opportunity for Polish Biotechnological Clusters.' Managing Global Transitions 13 (2): 171-18.

Ratajczak Mrozek, M., and M. Herbeć. 2013. 'Actie and Inactive Clusters in Polish Furniture Industry: The Industrial Network Approach.' Intercathedra 29 (3): 85-94.

Rifkin, J. 2012. Trzecia rewolucja przemysłowa. Katowice: Sonia Draga.

This paper is published under the terms of the Attribution-

NonCommercial-NoDerivatives 4.o International (CC BY-NC-ND 4.0)

License (http://creativecommons.org/licenses/by-nc-nd/4.o/). 